\title{
Co-production and biomass yield of amaranthus (Amaranthus hybridus) and tilapia (Oreochromis niloticus) in gravel-based substrate filter aquaponic
}

\author{
Taofik Ademola Babatunde ${ }^{1} \mathbb{D} \cdot$ Kabir Ibrahim ${ }^{1} \cdot$ Babangida Abdulkarim ${ }^{1}$. Nasir Hassan Wagini ${ }^{1}$. \\ Sama'ila Adamu Usman ${ }^{1}$
}

Received: 21 January 2019 / Accepted: 26 August 2019 / Published online: 5 September 2019

(c) The Author(s) 2019

\begin{abstract}
Purpose Aquaponics combine aquaculture with crop production in a mutual system. In this experiment, the growth of Amaranthus in aquaponics with tilapia fish was investigated.

Methods 500-liter water tanks containing tilapia fish at four initial stocking densities of 100, 150, 200, and $250 \mathrm{fish} / \mathrm{m}^{3}$ were used in triplicates, with a view to evaluate vegetable yields as influenced by fish biomass to water ratio. $1 \mathrm{~g}$ of Amaranthus seeds were sown in a $1 \mathrm{~m}^{2}$ planting trough, which contained gravel with a top layer of sandy soil. The pots were flooded with water from fish holdings by an aquarium pump.

Results The germination rate of Amaranthus was not significantly different across the experimental setup $(P>0.05)$. The growth rate of Amaranthus was significantly higher with increasing fish density $(P<0.05)$. The average lowest and highest of shoots dry biomass yield recorded were 0.36 and $1.95 \mathrm{~g} / \mathrm{plant}$ at 8 weeks after of sowing, and this corresponds to fish stocking densities of 100 and $250 \mathrm{fish} / \mathrm{m}^{3}$, respectively. A high positive correlation was found between the shoot dry biomass of Amaranthus and fish stocking density. The survival of tilapia fingerlings was not significant different, while the production levels were $5.62,4.77,4.57$, and $4.00 \mathrm{~kg} / \mathrm{m}^{2}$ in $100,150,200$, and $250 \mathrm{fish} / \mathrm{m}^{3}$.

Conclusions The growth of Amaranthus in this experiment demonstrated that the plant could effectively utilize the nitrogenous waste from fish tanks for biomass production, even at a higher concentration, while considerations for moderate fish density are only for fish health.
\end{abstract}

Keywords Aquaponics $\cdot$ Production $\cdot$ Amaranthus $\cdot$ Tilapia

\section{Introduction}

'Aquaponics' is the symbiotic assembly of plants and fish, where fish releases nitrogenous metabolic end products into the water, which are further metabolized by bacteria for the products to serve as nutrients for plants (Effendi et al. 2015). Aquaponics is a system made up of a looped arrangement of interactions between fish, vegetables and bacteria (Goddek et al. 2015). It also makes use of a flood drain systems in a filter bed, in which the plants growing media is flooded and drained systematically, thereby permitting the plant roots to

Taofik Ademola Babatunde attaofeeq@gmail.com

1 Department of Biology, Umaru Musa Ya'radua University, P.M.B. 2218, Katsina, Nigeria receive both water and air (Wongkiew et al. 2017). Aquaponics are appropriate in areas with limited land and/or water, because it produces more than three times the vegetables' biomass, with greatly reduced water compared to traditional agricultural methods (Tyson et al. 2011). It was reported that aquaponic production of tilapia requires use of less than $1 \%$ of the water required in pond culture for equivalent yields (McMurtry et al. 1990). In arid areas, agriculture sectors present a heavy demand for water (Barnett et al. 2005). Even though the production of fish using natural waters in this area is practical, integrating plant into fish farming provides the added benefits of water conservation, waste utilization, and increased fish and vegetable production per unit of area (Al-Hafedh et al. 2008).

In Nigeria, small-scale fish farming practices utilize earthen ponds, concrete, polythene, or plastic tanks for fish-rearing units. In general, in this area, aquaculture 
wastewater is not properly managed, as most farmers empty discharge into the natural environment through urban drainage system. Therefore, the adoption of aquaponics will permit greater control of aquaculture waste in this area. The fish tank can be set up in a way that the waste water can be recycled by the growing plant. Aquaculture waste is rich in nitrate (Mook et al. 2012), which is removed by the plant as a nutrient. The increasing concerns on a clean environment have encouraged the aquaculture industry to intensify the use of a recirculation system, which reduces the wastewater discharged from aquaculture facilities (Kim et al. 2000). Recirculating water from fish tanks for cultivation of vegetable plants has been successfully employed to grow different vegetable species (Endut et al. 2009). Small-scale aquaculture has been identified to play an important role in food security and the economy of most developing countries; it provides a cheaper source of protein and employment for a large number of people, especially in Africa or Asia (FAO 2007). Integration of vegetables in small-scale fish farming would add more to the benefit of this system not only in the area of pollution control, but also in terms of productivity. In addition, as global food production is projected to be declining and unimpeded population growth (Barrett and Odum 2000), inadequate nutrition is, therefore, evident for a larger percentage of the world's population. Aquaponics has been identified as a potential to augment traditional agricultural system, to meet global food challenges (Love et al. 2014; Okemwa 2015).

Amaranthus is quite a common vegetable in diets in many parts of the world. The plant is perennial and drought resistant, reaching up to $130 \mathrm{~cm}$ in height (Keeley et al. 1987). Its leaves are utilized as vegetables in soup, while its stem as animal feed. Its cultivation is characterized with rapid growth and efficient water utilization (Pospisil et al. 2006). The optimum fish-plant density ratio in aquaponics depends on source-water nutrient levels, the method of production, and the type of plant (Butterworth 2010). Different growing parameters suitable for vegetables such as basil in an aquaponic system have been reported by Somerville et al. (2014) and these include: $\mathrm{pH}$ (5.5-6.5), plant $/ \mathrm{m}^{2}$ (8-40), and growing time (5-6 weeks) (Somerville et al. 2014). While such information has been provided for some other vegetables such as: parsley, lettuce, cauliflower, broccoli, head cabbage, mangold, and cucumbers, Amaranthus has not been adopted this way. In this experiment, the growth of Amaranthus in a small-scale aquaponics system with tilapia fish was investigated with a view to evaluate both fish and vegetable yields and composite production as influenced by fish density. Detailed information on the environmental conditions essential for seed germination and the establishment of Amaranthus in different substrates is an important prerequisite for its adoption in an aquaponic environment.

\section{Materials and methods}

\section{Aquaponic system design}

A recirculatory aquaponic was set in the botanical garden at Umaru Musa Yaradua University, consisting of eight $500 \mathrm{~L}$ plastic tanks. Aeration was provided by an RS-390 air pump and adjusted to $3.5 \mathrm{~L} / \mathrm{min}$. Haizhi ${ }^{\circledR}$ aquarium pumps were used to transfer water to the planting bed at a rate of $5 \mathrm{~L} /$ min. Planting beds were made of builder's grade gravel. The planting trough was made of a rectangular pan: $100 \mathrm{~cm}$ long, $100 \mathrm{~cm}$ wide, and $20 \mathrm{~cm}$ deep. The troughs were arranged in such a way that water drained directly in the fish tank through perforated holes (Fig. 1). The average water retention time was $1.5 \mathrm{~h}$ in the fish tanks.

\section{Fish stocking}

Fingerlings of Tilapia zilli of body weight $0.82 \mathrm{~g}$ were obtained from the National Biotechnology Centre, Katsina, and stocked into tanks at an initial density of 100, 150, 200, and $250 \mathrm{fish} / \mathrm{m}^{3}$ in duplicates. The fish were fed thrice daily ad libitum for 15 min with a floating-pellet diet containing of $37 \%$ protein, at the rate of $5 \%$ of their body weight. Water $\mathrm{pH}$ was adjusted to 7.2 by the addition of $\mathrm{NaOH}$ solution at the rate of $167 \mathrm{mg} / \mathrm{L}$ to the storage tank.

\section{Seed sowing}

Amaranthus hybridus were collected from botanical gardens and planted by mixing 150 seeds with $500 \mathrm{~g}$ of sand and evenly distributing them on the seedbed. Sand was used to enhance seed germination. However, the plants were

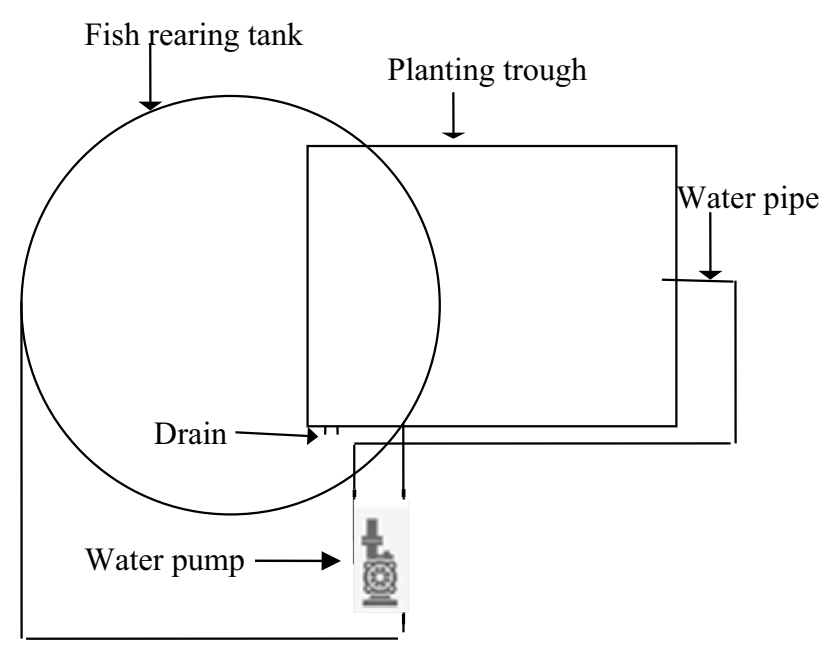

Fig. 1 Sketch of a single unit of aquaponic system used in the experiment 
periodically drained by stopping the water pump, to keep the plant roots well aerated and to promote nutrient uptake. This has also been reported to favors nitrification (Somerville et al. 2014; Fang et al. 2017; Wongkiew et al. 2017) as the media bed doubles up as a bio-filter and solids remover in our setup.

\section{Data collection}

Water quality parameters including $\mathrm{pH}$, dissolved oxygen (DO), water temperature, and total dissolved solid (TDS) were measured using multi-meters (YSI incorporated, USA). Ammonia-nitrate and nitrite were measured weekly following standard calorimetric methods (APHA 1995). Germination percentage and germination time were recorded for Amaranthus in all the experimental setup. Plant heights $(\mathrm{cm})$ of Amaranthus were recorded every week and the rates of growth in height (centimeters per day) were determined after 8 weeks. The fresh shoot biomass was recorded, and dry shoot biomass of the Amaranthus was obtained after the samples were oven-dried at $80{ }^{\circ} \mathrm{C}$ until constant weight (AlMufti et al. 1977). The final weight of the fish was recorded and the following parameters were calculated (Yue and Zhou 2008):

$$
\begin{aligned}
& \text { Weight gain (WG \%) } \\
& =\frac{\text { Final body weight }- \text { Initial body weight }}{\text { Initial body weight }} \times 100 \text {. }
\end{aligned}
$$

Specific growth ratio (SGR)

$$
=\frac{\text { In }(\text { final weight } / \text { initial weight })}{\text { days of the experiment }} \times 100 .
$$

Feed conversion ratio $(\mathrm{FCR})=\frac{\text { Feed consumed }(\mathrm{g} ; \text { dry weight })}{\text { Weight gain }(\mathrm{g})}$.

\section{Data analysis}

Analysis of variance of water parameters, seed germination percentages, and shoot dry mass yields under different fish density were performed using SPSS version 24. Statistical significance at $P<0.05$ was used and means were separated using Tukey's $T$ test. The height of Amaranthus was fitted to an exponential growth equation and the growth rate was obtained.

\section{Results and discussion}

\section{Water quality parameters}

A significant decrease $(P<0.05)$ in the DO concentration in the systems was observed, as the density increased (Table 1). The minimum and maximum DO levels $(6.2 \mathrm{mg} / \mathrm{L}$ and 7.0) were recorded in the highest and lowest densities of 250 and $100 \mathrm{fish} / \mathrm{m}^{3}$, respectively, despite these values being within the acceptable range for freshwater fish culture ( $>5 \mathrm{mg} / \mathrm{L}$ ) (Daniel et al. 2005). The majority of values for the water quality parameters in the fish tanks (Table 1) at different densities during the experiment showed that most of the parameters were within the tolerance for tilapia and the recommended value for recirculatory aquaculture systems. Among the important water quality issues in RAS is low-dissolved oxygen and highwaste metabolite concentrations in the culture medium (Sanni and Forsberg 1996). Maintaining good water quality environments is of primary significance in any design of RAS. The result of this work also demonstrated the suitability of gravel as a bio-filter in the RAS, even at a high density of fish stocking, thereby keeping the water quality within fish tolerance range in a simple aquaponic. A number of particulate solids in RAS such as uneaten food, fish excretion, algae, and microbes have been reported to dominate suspended solids in RAS (Chen et al. 1997). The use of gravel as a solid filter will be effective in control and management of such solids in recirculating systems.

The total ammonia-nitrate concentration was also found to increase from 0.13 to 1.05 , as the fish density increased from 100 to $250 \mathrm{fish} / \mathrm{m}$. It has been estimated that fish produce roughly $1.0-1.4 \mathrm{mg} / \mathrm{L}$ of total ammonium-nitrate for every $10 \mathrm{mg} / \mathrm{L}$ of DO consumed (Hagopian and Riley
Table 1 Physicochemical parameters of water in tilapiaAmaranthus aquaponic

\begin{tabular}{lcrrr}
\hline Water parameters & \multicolumn{4}{l}{ Fish stocking densities $\left(\right.$ Fish $\left./ \mathrm{m}^{3}\right)$} \\
\cline { 2 - 5 } & \multicolumn{1}{c}{100} & \multicolumn{1}{l}{150} & \multicolumn{1}{l}{200} \\
\hline Temperature ${ }^{\circ} \mathrm{C}$ & $28.50 \pm 0.41^{\mathrm{a}}$ & $28.70 \pm 0.33^{\mathrm{a}}$ & $29.60 \pm 0.51^{\mathrm{b}}$ & $29.70 \pm 0.62^{\mathrm{b}}$ \\
Dissolved oxygen $(\mathrm{mg} / \mathrm{L})$ & $7.00 \pm 0.01^{\mathrm{d}}$ & $6.80 \pm 0.03^{\mathrm{c}}$ & $6.50 \pm 0.03^{\mathrm{b}}$ & $6.20 \pm 0.04^{\mathrm{a}}$ \\
$\mathrm{pH}$ & $7.20 \pm 0.04^{\mathrm{c}}$ & $7.10 \pm 0.06^{\mathrm{b}}$ & $7.10 \pm 0.05^{\mathrm{b}}$ & $7.00 \pm 0.05^{\mathrm{a}}$ \\
Nitrite $(\mathrm{mg} / \mathrm{L})$ & $0.24 \pm 0.08^{\mathrm{d}}$ & $0.27 \pm 0.10^{\mathrm{c}}$ & $0.33 \pm 0.07^{\mathrm{b}}$ & $0.50 \pm 0.05^{\mathrm{a}}$ \\
Total ammonium-nitrate $(\mathrm{mg} / \mathrm{L})$ & $0.13 \pm 0.01^{\mathrm{d}}$ & $0.21 \pm 0.02^{\mathrm{c}}$ & $0.54 \pm 0.03^{\mathrm{a}}$ & $1.05 \pm 0.03^{\mathrm{a}}$ \\
Total dissolved solid $(\mathrm{mg} / \mathrm{L})$ & $460 \pm 12^{\mathrm{c}}$ & $520 \pm 10^{\mathrm{b}}$ & $550 \pm 11^{\mathrm{a}}$ & $580 \pm 25^{\mathrm{a}}$ \\
\hline
\end{tabular}


1998). Nitrogenous waste production rate in fish varies and their accumulation rate would be dependent of system design in terms of fish density, flow rate, and feeding, etc. In the current experiment, fish were held under similar conditions of aeration and water exchange. Accumulation of nitrate under increasing aeration as fish density increases would be an important area of investigation in our future research. The TDS was $460 \mathrm{mg} / \mathrm{L}$ in $100 \mathrm{fish} /$ $\mathrm{m}^{3}$ and it increased to $580 \mathrm{mg} / \mathrm{L}$ in $250 \mathrm{fish} / \mathrm{m}^{3}$ aquaponic tank which was significantly higher $(P<0.05)$. Aquaponic biofilters of different compositions are unique in relation to the dimension of particles removed (Miller and Semmens 2002). Sand filters have been described to function efficiently in eliminating particles down to $5 \mu \mathrm{m}$ (Fang et al. 2017).

One of the important parameters that affect bacteria growth and their productivity in aquaponic systems is the $\mathrm{pH}$ (Tyson et al. 2004). A higher stocking density of fish, resulted in a pH decrease in the aquaponic system, which is detrimental. Autotroph bacteria were said to have an optimum growing rate at $\mathrm{pH}$ range of 7.2 and 8.5 , while a $\mathrm{pH}$ of 7 is suitable for seed germination of Amaranthus (Segura-Nieto 2018) and many other plants (Laghmouchi et al. 2017; Zhang et al. 2010). Similarly, a high $\mathrm{pH}$ above 8 had been reported to affect seed germination negatively (Chauhan et al. 2006). Therefore, an aquaponic system suitable for plant germination and development will require proper monitoring of water $\mathrm{pH}$.

\section{Germination of Amaranthus}

The average germination percentage of Amaranthus ranged between 85 and $95 \%$ and no significant differences was found between the germination percentages of Amaranthus in the experimental setup $(P>0.05)$. The germination time ranged from 3 to 6 days for Amaranthus in all treatments. Moisture content in the seeds and that of the growth media are important factors in seed germination (Taylor and Harman 1990). In this experiment, a high germination percentage recorded, showed that Amaranthus can be planted directly in aquaponic systems with suitable system design. In aquaponics, seed environment water potential remains optimal. Seed germination has been established to be reduced as soil water potential is low (Maraghni et al. 2010). Protracted emergence of Amaranthus species observed in this study does not hinder the plants to grow. Similar observation was reported by Wu and Owen (2014).

\section{Shoot development and biomass yield}

Upon establishment, Amaranthus seedlings development was well correlated with fish stocking density in the tank (Fig. 2). The maximum plant height $(72 \mathrm{~cm})$ of Amaranthus was found in the seedlings irrigated with water from $125 \mathrm{fish} / \mathrm{m}^{3}$ fish tank, and this was significantly higher $(P<0.05)$. The relationship between the growth in height of Amaranthus with increasing density of fish in aquaponic systems was linear $(r=0.96)$, while the rates of growth in height (centimeters per day) of Amaranthus were 0.98, $1.05,1.16$ and 1.22 in $100,150,200$, and $250 \mathrm{fish} / \mathrm{m}^{3}$ of tilapia aquaponics, respectively. This study, therefore,
Fig. 2 Effect of fish density on the plant height of Amaranthus hybridus in tilapia aquaponic

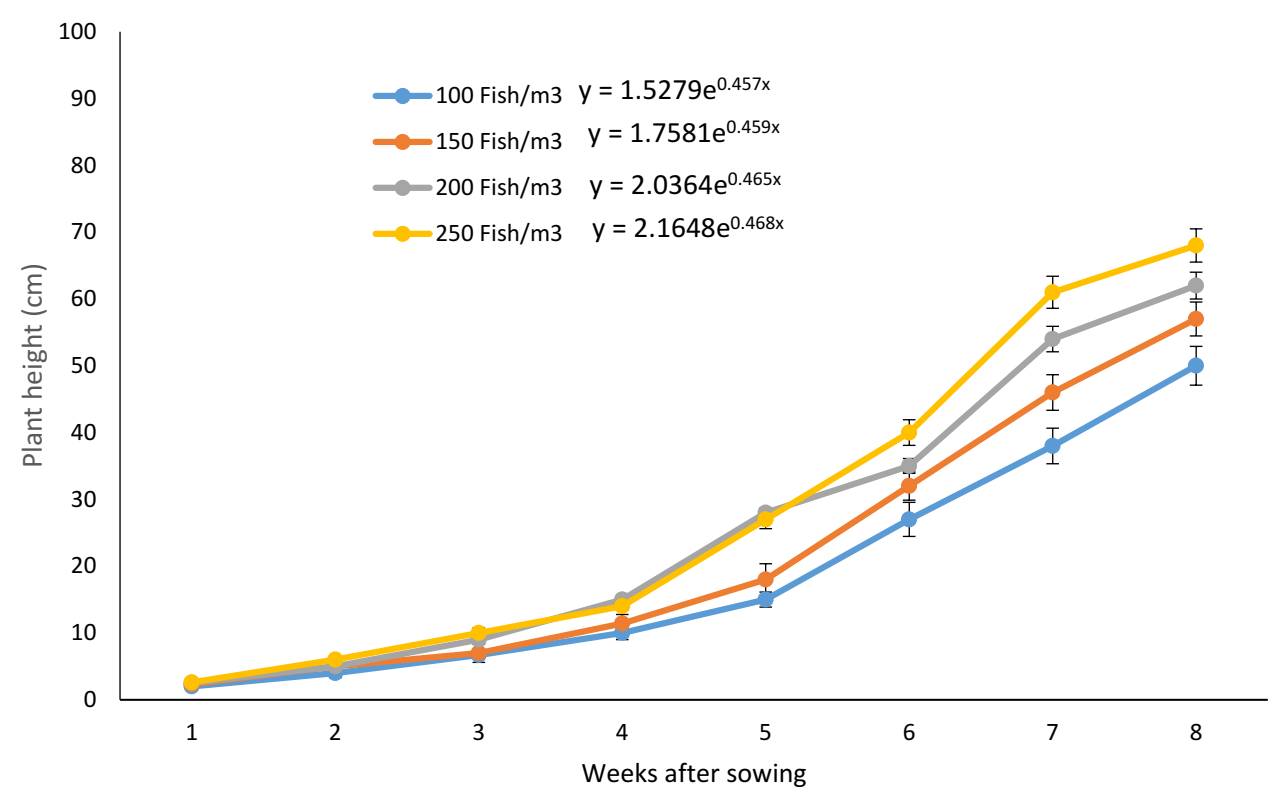


demonstrates that Amaranthus is responsive to aquaponic nutrients. Previous studies found Amaranthus to be the most sensitive plant to water regime out of the three plants (Amaranthus cruentus, Chenopodium quinoa and Pennisetum glaucum) studied by Adilson et al. (2017). The rate of the exponential growth curve for Amaranthus (Fig. 2) increased from 0.457 in $100 \mathrm{fish} / \mathrm{m}^{3}$ fish tank to 0.468 in $250 \mathrm{fish} / \mathrm{m}^{3}$. Therefore, the effect of increasing density of fish in the aquaponic tank and increasing food addition per unit volume of water resulted in increasing nitrate availability in wastewater. This accounted for the recorded increase in growth.

The fresh shoot biomass of Amaranthus (Fig. 3a) increases, as fish density increases with a value of 6.4 and 9.5 in 100 and $250 \mathrm{fish} / \mathrm{m}^{3}$ aquaponic tanks, respectively. The maximum dry shoot biomass per plant $(1.95 \mathrm{~g})$ was recorded in the Amaranthus, irrigated with water from a 250 fish $/ \mathrm{m}^{3}$ tank, and this was significantly higher $(P<0.05)$ compared to other treatments. Shoot biomass yield of Amaranthus was well influenced by the fish density in aquaponic tanks with a high coefficient of correlation value $r=0.99$. The combinations of NPK fertilizer were reported to cause a high growth and yield of Amaranths in different soil types (Masanobu et al. 2016). Similarly, our current findings showed that Amaranthus exhibit a similar trait in aquaponic environments. Unlike lettuce, which was reported to accumulate similar biomass irrespective of the range of fish stocking densities in aquaponics (Kratky 2010). The dry shoot biomass follow a similar trend, with fresh shoot biomass with an average of $0.36,1.31,1.45$, and $1.95 \mathrm{~g} /$ plants in $100,150,200$, and $250 \mathrm{fish} / \mathrm{m}^{3}$ of tank, respectively (Fig. 3b).

\section{Fish biomass production}

Tilapia fingerlings in this experiment grew at an average rate of $1.00,0.85,0.79$, and $0.70 \mathrm{~g} /$ day at stocking densities of $100,150,200$, and $250 \mathrm{fish} / \mathrm{m}^{3}$ to reach average sizes of 57.5, 49.0, 45.7, and 40.0 g, respectively (Table 2).
Table 2 Growth performance and feed utilization of tilapia in the experimental aquaponic

\begin{tabular}{lllll}
\hline & \multicolumn{4}{c}{ Fish stocking densities $\left(\right.$ Fish $\left./ \mathrm{m}^{3}\right)$} \\
\cline { 2 - 5 } & 100 & 150 & 200 & 250 \\
\hline Initial body mass (g) & 1.30 & 1.30 & 1.25 & 1.20 \\
Final body mass (g) & 57.50 & 49.00 & 45.70 & 42.00 \\
Weight gain (g) & 4323 & 3669 & 3556 & 3400 \\
Specific growth rate (SGR) & 2.92 & 2.79 & 2.77 & 2.70 \\
Feed conversion ratio (FCR) & 1.12 & 1.09 & 1.04 & 1.07 \\
\hline
\end{tabular}

These correspond to a production level of 5.62, 4.77, 4.57, and $4.00 \mathrm{~kg} / \mathrm{m}^{3}$. The average survival $(94.5 \%)$ was not significantly different between the fish densities tested, while the feed conversion ratio decreased as density increased (Table 2). Although the maximum stocking density used in the current research is not too high for growth and feed conversion, in tilapia an FCR of 1.07 is appreciable.

\section{Fish-to-vegetable mass ratio}

The estimated ratio of fish and vegetables produced in the current research was estimated at $0.53,0.52,0.48$, and $0.46 \mathrm{~kg}$ of plant per $\mathrm{kg}$ of fish in 100,150, 200, and $250 \mathrm{fish} /$ $\mathrm{m}^{3}$, respectively. Reports on several studies have shown that vegetable production to fish ratio in an aquaponics system can be optimized from small- to large-scale production, with varied levels of vegetable production per kilogram of fish grown (Effendi et al. 2015). Our current finding is a demonstration of this in simple aquaponics. Since the production period in this experiment was 2 months, four-to-five cycles of Amaranthus could be grown before the tilapia reached table size. The reduction in vegetables' production to fish ratio as the stocking density approaches $200 \mathrm{fish} / \mathrm{m}^{3}$ could be adduced to aeration level. All the experimental setup was subjected to similar aeration and flow rate. Increased aeration at higher fish density may upturn this trend as more nutrients would be metabolized, and made available for plant
Fig. 3 Effect of fish density on the fresh shoot biomass (a) and dry shoot biomass and (b) of Amaranthus hybridus in tilapia aquaponic
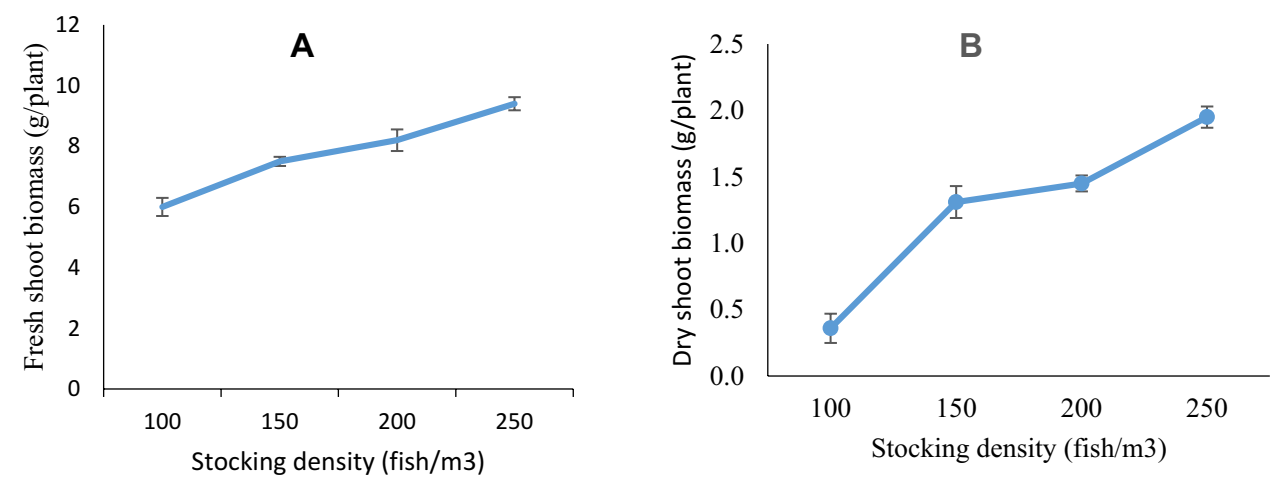
utilization. Aeration of the aquaponic nutrient solution had been found to result in an improved plant growth for some species (Morard and Silvestre 1996).

\section{Conclusion}

The increasing world population, depletion of natural resources, and reduction in crop cultivation areas has made aquaponics one of the promising ways for achieving food sustainability. This research demonstrated that germination and production of Amaranthus through direct sowing of seeds can be adopted in gravel substrate small-scale aquaponics. The system keeps the aquaponic water physicochemical parameters within the tolerance range for tilapia. A high germination rate up to $95 \%$ was recorded. Higher densities of fish promote a further growth and biomass production of Amaranthus in a linear increase. A higher density of tilapia $\left(250 \mathrm{fish} / \mathrm{m}^{3}\right)$ tends to reduce the average size of tilapia $(40.0 \mathrm{~g})$ at the end of the 8 week rearing period. Even though this production level is still satisfactory, as the FCR was 1.07 , increasing aeration and water flow concurrently with the density may improve this trend. The ratio of fish and vegetables produced in the current research was estimated at $0.53,0.52,0.48$, and $0.46 \mathrm{~kg}$ of plant per $\mathrm{kg}$ of fish in 100 , 150,200 , and $250 \mathrm{fish} / \mathrm{m}^{3}$, respectively.

Acknowledgements The authors acknowledge Umaru Musa Yaradu'a University, Kastina for the supporting this research. This research was funded by Tertiary Education Trust Fund (TETFund).

Open Access This article is distributed under the terms of the Creative Commons Attribution 4.0 International License (http://creativeco mmons.org/licenses/by/4.0/), which permits unrestricted use, distribution, and reproduction in any medium, provided you give appropriate credit to the original author(s) and the source, provide a link to the Creative Commons license, and indicate if changes were made.

\section{References}

Adilson JO, Walter QR Jr, Maria LGR, Adley CZ, Adriano J (2017) Amaranth, quinoa, and millet growth and development under different water regimes in the Brazilian Cerrado. Pesq Agropec Bras Brasília 52(8):561-571. https://doi.org/10.1590/s0100-204x2 017000800001

Al-Hafedh YS, Alam A, Beltagi MS (2008) Food production and water conservation in a recirculating aquaponic system in Saudi Arabia at different ratios of fish feed to plants. J World Aquac Soc 39(4):510-520. https://doi.org/10.1111/j.1749-7345.2008.00181.x

Al-Mufti MM, Sydes CL, Furness SB, Grime JP, Band SR (1977) A Quantitative analysis of shoot phenology and dominance in herbaceous vegetation. J Ecol 65(3):759-791. https://ci.nii.ac.jp/ naid/10021621589/en/
APHA (1995) Standard Methods for the examination of water and wastewater, 19th edn. American Public Health Association, Philadelphia

Barrett GW, Odum ER (2000) The twenty-first century: the world at carrying capacity. BioScience 50(4):363-368. https://doi. org/10.1641/0006-3568(2000)050[0363:TTFCTW]2.3.CO;2

Barnett TP, Adam JC, Lettenmaier DP (2005) Potential impacts of a warming climate on water availability in snow-dominated regions. Nature 438(7066):303. https://doi.org/10.1038/nature04141

Butterworth A (2010) Integrated multi-trophic aquaculture systems incorporating abalone and seaweeds. Report for Nuffield Australia Project (0914)

Chauhan BS, Gill G, Preston C (2006) Factors affecting seed germination of annual sow thistle (Sonchus oleraceus) in southern Australia. Weed Sci 54(5):854-860. https://doi.org/10.1614/ WS-06-047R.1

Chen S, Coffin DE, Malone RF (1997) Sludge production and management for recirculating aquacultural systems. J World Aquac Soc 28:303-314. https://doi.org/10.1111/j.1749-7345.1997.tb00278.x

Daniel S, Larry WD, Joseph HS (2005) Comparative oxygen consumption and metabolism of striped bass (Morone saxaatilis) and its hybrid. J World Aquac Soc 36(4):521-529. https://doi. org/10.1111/j.1749-7345.2005.tb00400.x

Effendi H, Utomo BA, Darmawangsa GM, Hanafiah DA (2015) Wastewater treatment of freshwater crayfish (Cherax quadricarinatus) culture with lettuce (Lactuca sativa). Intl J Appl Environ Sci 10(1):409-420

Endut A, Jusoh A, Ali N, Wan WNSN, Hassan A (2009) Effect of flow rate on water quality parameters and plant growth of water spinach (Ipomoea aquatica) in an aquaponic recirculating system. Desalin Water Treat 5(1-3):19-28. https://doi.org/10.5004/dwt.2009.559

Fang Y, Hu Z, Zou Y, Fan J, Wang Q, Zhu Z (2017) Increasing economic and environmental benefits of media-based aquaponics through optimizing aeration pattern. J Clean Prod 162:1111-1117. https://doi.org/10.1016/j.jclepro.2017.06.158

FAO (2007) The state of world fisheries and aquaculture. 2006. FAO Fisheries and Aquaculture Department, Rome, p 180 (ISBN: 978-92-5-105568-7)

Goddek S, Delaide B, Mankasingh U, Ragnarsdottir K, Jijakli H, Thorarinsdottir R (2015) Challenges of sustainable and commercial aquaponics. Sustainability 7(4):4199-4224. https://doi. org/10.3390/su7044199

Hagopian DS, Riley JG (1998) A closer look at the bacteria nitrification. Aquac Eng 18:223-244. https://doi.org/10.1016/S0144 -8609(98)00032-6

Keeley PE, Carter CH, Thullen RJ (1987) Influence of planting date on growth of Palmer amaranth (Amaranthus palmeri). Weed Sci 35:199-204. https://doi.org/10.1017/S0043174500079054

Kim S, Kong I, Lee B, Kang L, Lee M, Suh K (2000) Removal of ammonium-N from a recirculation aquacultural system using an immobilized nitrifiers. Aquac Eng 21:139-150. https://doi. org/10.1016/S0144-8609(99)00026-6

Kratky BA (2010) A suspended net-pot, non-circulating hydroponic method for commercial production of leafy, romaine, and semihead lettuce. Veg Crops 1:1-19

Laghmouchi Y, Belmehdi O, Bouyahya A, Senhaji NS, Abrini J (2017) Effect of temperature, salt stress and $\mathrm{pH}$ on seed germination of medicinal plant Origanum compactum. Biocatal Agric Biotechnol 10:156-160. https://doi.org/10.1016/j.bcab.2017.03.002

Love DC, Fry JP, Genello L, Hill ES, Frederick JA, Li X, Semmens K (2014) An international survey of aquaponics practitioners. PLoS One 9(7):102662. https://doi.org/10.1371/journal.pone.0102662

Maraghni MG, Gorai MNM, Neffati MM (2010) Seed germination at different temperatures and water stress levels, and seedling emergence from different depths of Ziziphus lotus. South Afr J Bot 76(3):453-459. https://doi.org/10.1016/j.sajb.2010.02.092 
Masanobu OM, Amzad H, Ichiro N, Hikaru A, Masanobu T, Prasanta CB, Akihiro N (2016) Effects of soil types and fertilizers on growth, yield, and quality of edible Amaranthus tricolor lines in Okinawa, Japan. Plant Prod Sci 19(1):61-72. https://doi. org/10.1080/1343943X.2015.1128087

McMurtry MR, Nelson PV, Sanders DC, Hodges L (1990) Sand culture of vegetables using recirculated aquacultural effluents. Appl Agric Res 5(4):280-284

Miller D, Semmens K (2002) Waste management in aquaculture. West Virginia University Extension Service Publication No. AQ02-1. USA, 8

Mook WT, Chakrabarti MH, Aroua MK, Khan GMA, Ali BS, Islam MS, Hassan MA (2012) Removal of total ammonia nitrogen (TAN), nitrate and total organic carbon (TOC) from aquaculture wastewater using electrochemical technology: a review. Desalination 285:1-13. https://doi.org/10.1016/j.desal.2011.09.029

Morard P, Silvestre J (1996) Plant injury due to oxygen deficiency in the root environment of soilless culture: a review. Plant Soil 184(2):243-254. https://doi.org/10.1007/BF00010453

Okemwa E (2015) Challenges and opportunities to sustainability in aquaponic and hydroponics systems. Int J Sci Res Innov Technol 2(11):54-76

Pospisil A, Pospisil M, Varga B, Svecnjak Z (2006) Grain yield and protein concentration of two Amaranth species (Amaranthus spp.) as influenced by nitrogen fertilization. Euro J Agron 1(25):250 253. https://doi.org/10.1016/j.eja.2006.06.001

Sanni S, Forsberg OI (1996) Modelling pH and carbon dioxide in single-pass seawater aquaculture systems. Aquac Eng 15(2):91-110. https://doi.org/10.1016/0144-8609(95)00003-8

Segura-Nieto M (2018) Biochemistry of amaranth proteins. In: Amaranth biology, chemistry, and technology. CRC Press, pp 75-106. https://ci.nii.ac.jp/naid/10005788251/en/ER. Accessed 15 June 2017

Somerville, C., Cohen, M., Pantanella, E., Stankus, A., \& Lovatelli, A. (2014). Small-scale aquaponic food production: integrated fish and plant farming. FAO Fisheries and Aquaculture Technical Paper, no. A (589), p 262

Taylor AG, Harman GE (1990) Concepts and technologies of selected seed treatments. Annu Rev Phytopathol 28(1):321-339. https:// doi.org/10.1146/annurev.py.28.090190.001541

Tyson RV, Simonne EH, White JM, Lamb EM (2004) Reconciling water quality parameters impacting nitrification in aquaponics: the $\mathrm{pH}$ levels. Proc Fla State Hort Soc 117:79-83

Tyson RV, Treadwell DD, Simonne EH (2011) Opportunities and challenges to sustainability in aquaponic systems. HortTech 21(1):613. https://doi.org/10.21273/HORTTECH.21.1.6

Wongkiew S, Hu Z, Chandran K, Lee JW, Khanal SK (2017) Nitrogen transformations in aquaponic systems: a review. Aquac Eng 76:9-19. https://doi.org/10.1016/j.aquaeng.2017.01.004

Wu C, Owen MD (2014) When is the best time to emerge: reproductive phenology and success of natural common water hemp (Amaranthus rudis) cohorts in the Midwest United States? Weed Sci 62(1):107-117. https://doi.org/10.1614/WS-D-13-00079.1

Yue Y-R, Zhou Q-C (2008) Effect of replacing soybean meal with cottonseed meal on growth, feed utilization, and hematological indexes for juvenile hybrid tilapia, Oreochromis niloticus $\times O$. aureus. Aquaculture 284:185-189. https://doi.org/10.1016/j.aquac ulture.2008.07.030

Zhang X, Zhang S, Xu X, Li T, Gong G, Jia Y, Li Y, Deng L (2010) Tolerance and accumulation characteristics of cadmium in Amaranthus hybridus L. J Hazard Mater 180(1-3):303-308. https:// doi.org/10.1016/j.jhazmat.2010.04.031

Publisher's Note Springer Nature remains neutral with regard to jurisdictional claims in published maps and institutional affiliations. 